\title{
ДИНАМІКА ПЕРЕХІДНИХ ПРОЦЕСІВ У НЕЗВОРОТНИХ КІНЕТИЧНИХ МОДЕЛЯХ
}

\author{
В.I. ТЕСЛЕНКО, О.Л. КАПІТАНЧУК
}

УдК 530.1, 536-3

(C) 2012

Інститут теоретичної фізики ім. М.М. Боголюбова НАН України

(Вул. Метрологічна, 14б, Київ 03680; e-mail: vtes@bitp. kiev. ua)

\begin{abstract}
Для опису процесу незворотного зв'язування молекул ліганду і рецептора у розчині побудовано мікроскопічну модель відкритої системи, що взаємодіє із зовнішнім середовищем та зазнає квазікласичних флуктуацій своєї енергії. Отримано аналітичні вирази для ймовірностей переходів між нестаціонарними станами системи, що усереднюються як за рівноважними коливаннями у середовищі, так і за стаціонарними станами у системі. Для незворотної моделі із трьома кінетичними стадіями знайдено явні залежності констант швидкостей переходів від концентрації ліганду, в'язкості розчину та температури.
\end{abstract}

\section{1. Вступ}

Під час дослідження нерівноважних процесів у різних фізичних, хімічних та біологічних системах, наприклад, транспортування екситонів у низьковимірних впорядкованих структурах, перенесення електронів у донорно-акцепторних молекулярних комплексах, динаміки ліганд-індукованих конформаційних перетворень у рецепторних біомакромолекулах тощо, важливим є знання конкретних залежностей величин, що спостерігаються, від внутрішніх (мікроскопічних) та зовнішніх (макроскопічних) параметрів. Останнім часом ця проблема набула додаткової актуальності, зокрема за прикладання методів спектроскопії й атомно-силової мікроскопії до поодиноких молекул у гомогенному та гетерогенному оточеннях [1-8]. Завдяки цьому виникла унікальна можливість спостереження у реальному часі нестаціонарної (перехідної) еволюції окремих електронно-коливальних станів індивідуальних молекул, викликаної зовнішніми збуреннями, що прикладаються до системи. 3 фізичної точки зору такий процес є аналогічним до миттєвого заповнення певного початкового стану системи, що потім спустошується за перерозподілення між іншими станами, які, в свою чергу, теж поступово заповнюються, та за максимального заповнення обертаються на затухання за деяким каналом незворотного розпаду, що додається. При цьому за послідовної постановки задачі у незворотній кінетичній моделі тре- ба проводити мікроскопічний опис релаксаційних переходів між флуктуючими станами відкритої динамічної системи, що контактує з оточуючим середовищем.

Мікроскопічний підхід до кінетичного опису процесів релаксації у квантових системах за присутності флуктуацій енергетичних параметрів розвивався у багатьох роботах [9-21]. При цьому основну увагу приділяли аналізу низькоамплітудних випадкових модуляцій різниць енергій між перехідними станами $[9,10,13,14,18,19]$ та впливу зовнішнього стохастичного поля на найбільш повільні швидкості переходів, що лімітують встановлення у системі остаточної термодинамічної рівноваги $[11-17,20,21]$. У той самий час добре відомо, що у відкритих молекулярних системах взагалі [22-25] та у більшості біологічних систем зокрема $[26,27]$ заселеності станів, що експериментально спостерігаються упродовж значних проміжків часу, є суттєво нестаціонарними величинами, які при досягненні своїх максимальних значень експоненційно прямують до нуля, не підпорядковуючись у загальному випадку рівноважним больцманівським співвідношенням. Тому кількісний опис перехідних станів відкритих квантових систем, що контактують з флуктуючим молекулярним оточенням, потребує більш загального підходу. По-перше, такий підхід має бути кінетично узгодженим на різних шкалах часів, охоплюючи водночас як дуже швидке заповнення перехідних станів, так і їх досить повільне спустошення. По-друге, у цьому підході треба одночасно враховувати як мікроскопічну релаксаційну взаємодію, що приводить до переходів між енергетичними рівнями, так і термодинамічні флуктуації, що випадково змінюють положення цих рівнів за певною статистикою [26,27]. $\mathrm{У}$ цій роботі ми побудуємо мікроскопічну модель нестаціонарних станів відкритої системи, що знаходиться у контакті із рівноважним молекулярним оточенням та зазнає квазікласичних флуктуацій своєї енергії; далі отримаємо для заселенностей цих станів узгоджене керуюче рівняння, яке усереднюється як за флуктуаціями в системі, так і за коливаннями в оточенні; потім в аналітичному вигляді визна- 
чимо усереднену швидкість переходів між станами; i нарешті, покажемо, що в узагальненій незворотній кінетичній моделі переходів між трьома станами відповідні величини швидкостей переходів містять необхідну інформацію для опису динаміки перехідних станів залежно від температури, в'язкості розчину та концентрації діючої речовини.

\section{2. Мікроскопічна модель системи і керуюче рівняння}

Розглянемо одно-одночастинкову модель відкритої системи (ВС), яка залежно від початкової умови й за даної температури $T$ еволюціонує у часі, здійснюючи обмін коливальними квантами (фононами) з оточуючим середовищем (ОС). Стани $|m\rangle$ ВС будемо розрізняти за контактними положеннями виділеної одиничної молекули, яку будемо називати лігандом, по відношенню до молекул в об'ємі розчину та виділеного центру зв'язування в певній макромолекулі, яку будемо називати рецептором. Для рецептора обмежимось врахуванням тільки одного контакту з лігандом, котрий будемо характеризувати енергією зв'язку $E_{1}$. Відповідний зв'язаний стан ліганду з рецептором позначимо $|1\rangle$. Беручи до уваги узагальнення одноцентрової моделі на незворотний випадок, поряд 3 цим станом припустимо існування стану $|0\rangle$ з енергією $E_{0}$, в якому цілісність ліганду як окремої молекули може порушуватись. Зокрема, у такому стані ліганд може розпадатися на складові за каталітичного процесу або як субодиниця входити до структурнотрансформованого стану десенситизованого рецептора. При цьому різниця енергій між станами зв'язаного з центром і деградованого ліганду буде завжди набагато вищою за теплову енергію $E_{1}-E_{0} \gg k_{\mathrm{B}} T$, де $k_{\mathrm{B}}$ - стала Больцмана.

На відміну від рецептора, де можна спрощено зважати тільки на один його контакт з лігандом ("одноодночастинкова" модель рецептора), кількість контактів ліганду з молекулами в об'ємі розчину є макроскопічно великою. При цьому слід розрізняти число $\aleph_{V}$ таких контактів 3 довільною молекулою у гомогенній (власно об'ємній) фазі, коли конкретне положення ліганду по відношенню до рецептора $є$ невизначеним, з числом $\aleph_{S}$ контактів із виділеною молекулою у гетерогенній (на межі поділу) фазі, коли ліганд знаходиться у безпосередній близькості від центру зв'язування. У результаті загальна кількість можливих станів $|m\rangle$ ВС буде характеризуватися величиною $M+1=2+\aleph_{S}+\aleph_{V} N(m=0,1,2, \ldots, M)$, де
$N=1 / C$ - число молекул розчинника у розрахунку на один ліганд відносної концентрації $C$.

Подальший аналіз динаміки ВС має на увазі кількісний опис амплітудних та кінетичних характеристик переходів, які здійснюються між різним станами ВС. Така динаміка залежить від імовірностей переходів за даних початкових умов, флуктуаційних параметрів ВС й характеристик релаксаційної взаємодії між $\mathrm{BC}$ та ОС. У ролі початкової умови приймаємо стан ВC, що відповідає довільному контакту ліганду з довільною молекулою об'ємної фази під час рівноймовірного розподілу ліганду між такими станами та ергодичного наближення для переходів за принципом "кожен-з-кожним".

Розгляд такого роду процесів є загально типовим. В адіабатичному наближенні вони зображуються рухом уздовж багатовимірних поверхонь потенціальної енергії, які, зазвичай, відносяться до основного стану ВС. У простих ВС, коли траєкторія руху визначена, цей рух можна приблизно вважати одновимірним, а його траєкторію асоціювати 3 координатою реакції. Таке наближення виправдовується, наприклад, для відносної довжини хімічного зв'язку у двоатомних молекулах. Однак у випадках, коли виділена частота переходів між основним та збудженим станами ВС є порядку чи менше характерної фононної частоти в ОС, адіабатичне наближення спростовується [28]. У цих випадках переходи здійснюються не за результатом сильних адіабатичних взаємодій, що формують потенціальні поверхні неперервного руху у просторі енергій основного та збуджених станів ВС, а відбуваються виключно за рахунок більш слабких неадіабатичних взаємодій, що єднають між собою дискретні (квантові) зміщення ядер молекул у ВС та ОС. У білінійному наближенні для таких зміщень неадіабатичні переходи носять, в основному, однофононний характер [27]. Це суттєво полегшує їх аналіз. Але для коректного розгляду таких переходів у другому порядку теорії збурень за величиною неадіабатичної взаємодії виникає необхідність у точному (без застосування теорії збурень) підрахунку певних адіабатичних поправок до енергій станів. Такі поправки, що часто враховуються у вигляді стохастичних доданків $[9,10,12,13,18-$ $21,26]$, можуть бути значними, як у класичній границі для квазіізоенергетичних переходів [27], частота яких мала відносно теплової частоти. У квантовій границі ендоергічних переходів, частота яких набагато вища за теплову частоту, ці поправки можуть приводити до збільшення ймовірностей переходів [18]. 
Зважаючи на зазначене, енергію $E_{m}(t)$ стану $|m\rangle$ $\mathrm{BC}$ задамо у загальному вигляді $E_{m}(t)=E_{m}+$ $\Delta E_{m}(t)$, де $\Delta E_{m}(t)$ - стохастичний доданок до стаціонарної величини $E_{m}$. Переходи між станами ВС тепер здійснюються на фоні випадкових зсувів енергії $\Delta E_{m}(t)$ від їх середніх значень $E_{m}$. Тому для коректного опису фізичних величин, що спостерігаються, треба робити усереднення за стохастичними реалізаціями такого процесу (надалі позначається як $\langle\langle\ldots\rangle\rangle)$. Зокрема, треба знаходити усереднені заселеності станів $P_{m}(t)=\left\langle\left\langle p_{m}(t)\right\rangle\right\rangle\left(p_{m}(t)=\left\langle m\left|\rho_{0}(t)\right| m\right\rangle\right.$ - неусереднені заселенності, $\rho_{0}(t)$ - матриця густини ВC), а також усереднені ймовірності переходів $W_{m m^{\prime}}$ між станами (знаходяться у наступному розділі).

Визначимо гамільтоніан повної системи (ПС):

$H(t)=H_{0}(t)+V+H_{T}$

як суму гамільтоніана ВC

$H_{0}(t)=\sum_{m} E_{m}(t)|m\rangle\langle m|$,

гамільтоніана ОС

$H_{T}=\sum_{\lambda} \hbar \omega_{\lambda}\left(b_{\lambda}^{\dagger} b_{\lambda}+1 / 2\right)$

та оператора білінійної взаємодії ВС та ОС

$V=\sum_{m m^{\prime}}\left(1-\delta_{m m^{\prime}}\right) \sum_{\lambda} \chi_{m m^{\prime}}^{\lambda}\left(b_{\lambda}^{\dagger}+b_{\lambda}\right)|m\rangle\left\langle m^{\prime}\right|$,

де $b_{\lambda}^{\dagger}$ i $b_{\lambda}$ - оператори народження і знищення в ОС $\lambda$-го нормального коливання частоти $\omega_{\lambda}$. За рахунок такого неадіабатичного зв'язку між $\mathrm{BC}$ та ОC з параметрами $\chi_{m m^{\prime}}^{\lambda}(4)$ процеси народження і знищення фононів в ОС супроводжують переходи між станами ВС при виконанні у ПС закону збереження енергії ( $\hbar$ - стала Планка).

Запишемо стохастичне рівняння Ліувілля для матриці густини $\rho(t)$ ПС у вигляді

$\dot{\rho}(t)=-\frac{i}{\hbar}[H(t), \rho(t)]$.

Слід від $\rho(t)$ за станами ОС складає нерівноважну матрицю густини $\mathrm{BC} \rho_{0}(t)=\operatorname{tr}_{T} \rho(t)$, еволюція котрої вважається найбільш повільною у ПС і характеризується часами релаксаційних переходів $\tau_{\mathrm{tr}}$. Тому за більш швидких часів $\tau_{\text {vib }} \ll \tau_{\text {tr }}$ встановлення в ОС коливної рівноваги матриця густини ПС факторизується $\rho(t)=\rho_{0}(t) \rho_{T}$, де $\rho_{T}=e^{-H_{T} / k_{\mathrm{B}} T} / \operatorname{tr}_{T} e^{-H_{T} / k_{\mathrm{B}} T}$
- рівноважна матриця густини ОС. Крім того, загрублене рівняння для $\rho_{0}(t)=\rho_{d}(t)+\rho_{n d}(t)$ за дії діагонального і недіагонального проекційних операторів $T_{d}$ i $T_{n d}$ замикається на діагональну частину матриці густини ВС $\rho_{d}(t)=\sum_{m}\left\langle m\left|\rho_{0}(t)\right| m\right\rangle|m\rangle\langle m|=T_{d} \rho_{0}(t)$, $\left(\rho_{n d}(t)=T_{n d} \rho_{0}(t)\right)$. Застосовуючи метод НакажимиЦванціга [29, 30] до стохастичного рівняння (5) [27], набуваємо загрублене керуюче рівняння для $\rho_{d}(t)$ :

$\dot{\rho}_{d}(t)=-\frac{1}{\hbar^{2}} \int_{0}^{t} d \tau T_{d}\left[V, U(\tau)\left[V, \rho_{d}(t-\tau)\right] U^{\dagger}(\tau)\right]$,

де $U(\tau)=\hat{D} \exp \left\{-\frac{i}{\hbar} \int_{0}^{\tau} d t^{\prime}\left[H_{0}\left(t^{\prime}\right)+H_{T}\right]\right\}$ є стохастичним оператором еволюцї $(\hat{D}$ - оператор хронологічного упорядкування Дайсона). Як видно з (6), загрублена на часах дискретизації $\Delta t>\tau_{\text {vib немарков- }}$ ська еволюція ВС у другому порядку теорії збурень за величиною взаємодії між ВC і ОC (4) визначається еволюцією лише діагональної частини матриці густини ВС й керується діагональними стохастичними флуктуаціями у незбуреній ВС (2), що відбуваються на фоні рівноважних коливних процесів в ОС (3).

\section{3. Кінетичні рівняння та усереднені ймовірності переходів}

Знання конкретного вигляду гамільтоніана ПС (1)(4) дозволяє отримати з (6) замкнену систему немарковських кінетичних рівнянь для неусереднених заселенностей станів ВС:

$\dot{p}_{m}(t)=-\frac{2}{\hbar^{2}} \operatorname{Re} \sum_{m^{\prime}} \int_{0}^{t} d \tau\left[Q_{m m^{\prime}}(\tau) p_{m}(t-\tau)-\right.$

$\left.-Q_{m^{\prime} m}(\tau) p_{m^{\prime}}(t-\tau)\right]$

Тут $Q_{m m^{\prime}}(\tau)=\sum_{\lambda}\left|\chi_{m m^{\prime}}^{\lambda}\right|^{2} f_{m m^{\prime}}(\tau) R_{\lambda}(\tau) e^{i \Omega_{m m^{\prime}} \tau}=$ $Q_{m^{\prime} m}^{*}(\tau)$ - залежні від часу коефіцієнти переходів, $f_{m m^{\prime}}(\tau)=f_{m^{\prime} m}(-\tau)=f_{m m^{\prime}}^{*}(-\tau)=e^{i \int_{0}^{\tau} \Delta \Omega_{m m^{\prime}}\left(t^{\prime}\right) d t^{\prime}}$ - стохастичні функціонали від відносних випадкових зміщень частоти $\Delta \Omega_{m m^{\prime}}(t)=\left[\Delta E_{m}(t)-\Delta E_{m^{\prime}}(t)\right] / \hbar$ при частоті переходів $\Omega_{m m^{\prime}} \equiv\left(E_{m}-E_{m^{\prime}}\right) / \hbar, R_{\lambda}(\tau)=$ $R_{\lambda}^{*}(-\tau)=n\left(\omega_{\lambda}\right) e^{i \omega_{\lambda} \tau}+\left[1+n\left(\omega_{\lambda}\right)\right] e^{-i \omega_{\lambda} \tau}-$ однофононна кореляційна функція, $n\left(\omega_{\lambda}\right)=\left[e^{\hbar \omega_{\lambda} / k_{\mathrm{B}} T}-1\right]^{-1}-$ функція розподілу Бозе для коливань. Головна складність розв'язку рівнянь (7) полягає у немарковості їх підінтегральних виразів та необхідності усереднення стохастичних функціоналів у явному вигляді. 
Оскільки положення енергетичних рівнів залежать від термодинамічних флуктуацій, які при кімнатній температурі відповідають міжмолекулярним зіткненням із частотою $\nu \equiv \omega_{T} / 2 \pi=k_{\mathrm{B}} T / 2 \pi \hbar \cong 6 \cdot 10^{12} \mathrm{c}^{-1}$, то середні проміжки часу між послідовними зіткненнями $\tau_{\nu}=\nu^{-1}$ будуть набагато меншими за час переходів $\tau_{\nu} \ll \tau_{\mathrm{tr}}$. Як наслідок, стохастичне усереднення функціоналів, що стоять у правій частині $(7)$, за часів дискретизації $\Delta t>\tau_{\nu}$ факторизується $\left\langle\left\langle f_{m m^{\prime}}(\tau) p_{m}(t-\tau)\right\rangle\right\rangle=F(\tau) P_{m}(t)$. Тут припущено, що відносні флуктуації частоти $\Delta \Omega_{m m^{\prime}}(t)=\Delta \Omega(t)$ не залежать від номерів станів ВС:

$F(\tau)=\left\langle\left\langle e^{i \int_{0}^{\tau} \Delta \Omega\left(t^{\prime}\right) d t^{\prime}}\right\rangle\right\rangle=F_{m m^{\prime}}(\tau)=\left\langle\left\langle f_{m m^{\prime}}(\tau)\right\rangle\right\rangle$.

Також враховано, що у другому порядку теорії збурень немарковість не проявляється [27] й тому $P_{m}(t-$ $\tau) \approx P_{m}(t)$

Вигляд кореляційної функції $F(t)$ від стохастичних зміщень частоти (8) диктується конкретною моделлю для випадкових процесів, що розглядаються. Проте для найбільш поширених процесів, таких як загашений дихотомічний процес, Гаусів марковський процес або білий шум, справедливим є просте експоненціальне представлення Кубо $F(t)=e^{-\gamma t}$, де $\gamma$ має зміст флуктуаційної півширини рівня. Остання звичайно напряму пов'язується із коефіцієнтом тертя, який згідно із законом Стокса є лінійно пропорційним до в'язкості $[12,13]$. Можна показати [26, 27], що параметр $\gamma$ виражається через стандартне відхилення енергії $\varepsilon$ та середню частоту $\nu$ флуктуацій як $\gamma=\varepsilon^{2} /\left(4 \pi^{2} \hbar^{2} \nu\right)$. Тому по відношенню до характерного часу $\tau_{\operatorname{tr}}$ для зміни $P_{m}(t)$ час $\tau_{\gamma}=\gamma^{-1}=\left(4 \pi^{2} \hbar^{2} \nu\right) / \varepsilon^{2}$ для зміни кореляційної функції $F(t)=e^{-t / \tau_{\gamma}} \in$ достатньо малим $\tau_{\gamma} \ll \tau_{\text {tr }}$. Ця обставина дозволяє безпечно спрямувати верхню границю інтеграла у правій частині рівняння (7) до нескінченності, що еквівалентно нехтуванню на часах дискретизації $\Delta t>\tau_{\gamma}$ залежністю від $t$ в інтегральних кінетичних коефіцієнтах.

Таким чином, для коректного проведення стохастичного усереднення рівнянь (7) необхідно: а) факторизувати добутки стохастичних функціоналів; б) знехтувати немарковістю у заселенностях та кінетичних коефіцієнтах; в) записати кореляційну функцію (8) у вигляді $F(t)=e^{-\gamma t}$, що містить інформацію про стохастичні флуктуації через ефективний коефіцієнт в'язкості $\gamma$. За такого алгоритму немарковські стохастичні рівняння (7) спрощуються, зводячись до кінетичних рівнянь для заселенностей $P_{m}(t)$, що спостерігаються:

$\dot{P}_{m}(t)=-P_{m}(t) \sum_{m^{\prime}} W_{m m^{\prime}}+\sum_{m^{\prime}} P_{m^{\prime}}(t) W_{m^{\prime} m}$
Важливо, що на відміну від стандартних кінетичних рівнянь балансового типу [17] у рівняннях (9) відповідні ймовірності переходів:

$$
\begin{aligned}
& W_{m m^{\prime}}=\frac{2 \gamma}{\hbar^{2}} \sum_{\lambda}\left|\chi_{m m^{\prime}}^{\lambda}\right|^{2} \times \\
& \times\left[\frac{n\left(\omega_{\lambda}\right)}{\gamma^{2}+\left(\Omega_{m m^{\prime}}+\omega_{\lambda}\right)^{2}}+\frac{n\left(\omega_{\lambda}\right)+1}{\gamma^{2}+\left(\Omega_{m m^{\prime}}-\omega_{\lambda}\right)^{2}}\right]
\end{aligned}
$$

$\epsilon$ усередненими як за рівноважними коливаннями в OC, так і за термодинамічними флуктуаціями у ВС. Попри те, що ці процеси відбуваються швидше від часів дискретизації спостережень у системі $\tau_{\mathrm{vib}} \sim \tau_{\nu} \sim$ $\tau_{\gamma}<\Delta t \ll \tau_{\mathrm{tr}}$, вони не відкидаються (не відфільтровуються), а послідовно враховуються за їх усередненими характеристиками, як то за числами заповнення $n\left(\omega_{\lambda}\right)$ для коливань в ОС та за коефіцієнтом в'язкості $\gamma$ для флуктуацій у ВС. У результаті загрублений опис (9), (10) редукує швидкі процеси до рівноважних (для коливань) та стаціонарних (для флуктуацій) й усереднено відслідковує кінетику більш повільних нерівноважних (незворотних, нестаціонарних) процесів.

\section{4. Кінетика узагальненого тристадійного незворотного процесу}

Загальних співвідношень, що встановлюють залежність динамічних характеристик процесу від його кінетичних параметрів, не існує. Застосування наближених балансових кінетичних рівнянь (9) із константами швидкостей переходів у вигляді (10) дає загрублений опис перехідних процесів на фоні вже завершених рівноважних і стаціонарних стадій. За такої постановки задачі особливий інтерес викликають відкриті системи, стани яких спустошуються згідно 3 експоненціальним законом із заданими константами швидкостей. Суттєвим аспектом проблеми є побудова простих аналітичних моделей, що вказують на головні фактори, за рахунок яких варіація констант швидкостей на окремих кінетичних стадіях може впливати на певні динамічні характеристики процесу.

Прикладом такої моделі є система трьох станів $i=1,2,3$ при початковій умові $P_{3}(0)=1 ; P_{2}(0)=$ $P_{1}(0)=0$. За наявності незворотної кінетичної стадії стани системи спустошуються із часом, причому їх сумарна заселенність експоненційно спадає від одиниці до нуля. Цю незворотну стадію, що виходить із стану $i=1$, будемо характеризувати константою швидкості $k$. Подальшою метою буде співставлення 


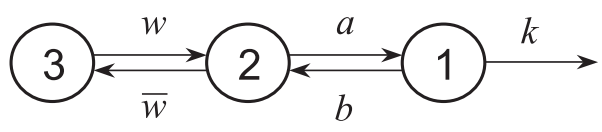

Рис. 1. Структурна схема незворотної кінетичної моделі переходів між трьома станами

цієї системи із загальною системою (9) для кінетичної задачі, яку ставили у другому розділі. Для цього стан $i=1$ має моделювати точковий контактний стан зв'язаного ліганду з рецептором, стан $i=2$ має поєднувати $\aleph_{S}$ контактних стани ліганду у гетерогенній фазі, а стан $i=3$ - охоплювати сукупність $\aleph_{V} N$ станів ліганду у гомогенній (об'ємній) фазі, причому кількість локальних контактів ліганду в кожній фазі може бути різною. Тому в (9) можна вважати $W_{21}=W_{31}=\ldots=W_{\aleph+11} \equiv A, W_{12}=W_{13}=\ldots=$ $W_{1 \aleph+1} \equiv B, W_{2 \aleph+2}=W_{3 \aleph+2}=\ldots=W_{\aleph+1 \aleph+2}=$ $W_{2 \aleph+3}=\ldots=W_{\aleph+1 \aleph(N+1)+1} \equiv \bar{W}, W_{\aleph+22}=\ldots=$ $W_{\aleph+2 \aleph+1}=W_{\aleph+32}=\ldots=W_{\aleph(N+1)+1 \aleph+1} \equiv W$. Це еквівалентно припущенню про ергодичну однаковість ймовірностей переходів окремих стадій за об'єднання станів кожної фази у відповідний сукупний стан. Також за принципу мікроскопічної зворотності процесів треба врахувати деякий стан $i=0$, ймовірність переходів з якого у стан $i=1$ буде набагато меншою від інших ймовірностей переходів: $W_{01} \ll W, \bar{W}, A, B, W_{10}$. Це за спрямування енергії такого стану до мінус нескінченності $E_{0} \rightarrow-\infty$ еквівалентно наданню системі незворотної кінетичної стадії із ймовірністю переходів $k \equiv W_{10}$. У подальшому будемо розглядати систему трьох станів як базову. Така система становить спрощений випадок $\aleph_{V}=\aleph_{S}=N=1$ для загального випадку $M+1$ станів (9), де $\aleph_{V, S} \geq 1 ; N \geq 1$. Щоб розрізняти ці випадки, позначимо ймовірності переходів у базовій системі прописними символами $a, b, w, \bar{w}$. Далі, отримавши точний розв'язок для випадку трьох станів, зіставимо кожну таку ймовірність iз ймовірностями для загального випадку $A, B, W, \bar{W}$. Зразу відзначимо, що $B=b$, бо ці ймовірності не залежать від чисел контактних станів у різних фазах.

Схему базової моделі для переходів між трьома станами із незворотною стадією подано на рис. 1. Строгий розв'язок кінетичної задачі для заселенностей станів у цій моделі шукається із системи трьох диференціальних рівнянь, які зводяться до системи дев'яти алгебраїчних рівнянь з дев'ятьма невідомими. Точний розв'язок цієї задачі має такий вигляд:

$P_{3}(t)=w \bar{w} \sum_{i=1}^{3}\left(\lambda_{i}-b-k\right) e^{-\lambda_{i} t} \times$ $\times\left[\left(\lambda_{i}-w\right) \prod_{j=1 ; j \neq i}^{3}\left(\lambda_{i}-\lambda_{j}\right)\right]^{-1}$

$P_{2}(t)=w \sum_{i=1}^{3}\left(b+k-\lambda_{i}\right) e^{-\lambda_{i} t}\left[\prod_{j=1 ; j \neq i}^{3}\left(\lambda_{i}-\lambda_{j}\right)\right]^{-1}$

$P_{1}(t)=w a \sum_{i=1}^{3} e^{-\lambda_{i} t}\left[\prod_{j=1 ; j \neq i}^{3}\left(\lambda_{i}-\lambda_{j}\right)\right]^{-1}$

де $\lambda_{1}, \lambda_{2}, \lambda_{3}$ - дійсні позитивні зростаючі корені характеристичного рівняння

$\lambda^{3}-\lambda^{2}(w+\bar{w}+a+b+k)+$

$+\lambda[(w+\bar{w})(b+k)+a(w+k)]-w a k=0$.

Розв'язок (11), (12) є математично строгим, бо фактично виключає точний збіг двох або трьох коренів. Кінетичний опис заселенностей $P_{i}(t)(11)$ проводиться на всій допустимій шкалі релаксаційних часів $\lambda_{3}^{-1}<\lambda_{2}^{-1}<\lambda_{1}^{-1}$ за умови неможливості обертання на нуль попарних різниць між коренями, що стоять у знаменниках експоненційних компонент. При цьому треба знати конкретні величини коренів у явній залежності від параметрів характеристичного рівняння (12). Точна формула Кардано не надає наочності дійсним кореням кубічного рівняння. Більш наглядним виявляється алгоритм Вієта, який запроваджує роздільний масштаб для шкали часів у явній формі. Застосовуючи цей алгоритм, рівняння (12) тотожно трансформується у вигляд

$\lambda^{3}-\lambda^{2} \tau_{\text {eq }}^{-1}+\lambda\left(\tau_{\text {eq }} \tau_{\text {st }}\right)^{-1}-\left(\tau_{\text {eq }} \tau_{\text {st }} \tau_{\text {eff }}\right)^{-1}=0$,

де кінетичні процеси розбиті за величинами найбільш характерних для них часів. Тут найшвидкіші процеси визначаються часом встановлення у системі локальної рівноваги

$\tau_{\text {eq }}=\left(\lambda_{1}+\lambda_{2}+\lambda_{3}\right)^{-1}=(w+\bar{w}+a+b+k)^{-1}$,

процеси, що відображають проміжну рівновагу між станами системи, характеризуються стаціонарним чаcom

$$
\begin{aligned}
& \tau_{\mathrm{st}}=\left(\lambda_{1}+\lambda_{2}+\lambda_{3}\right)\left(\lambda_{1} \lambda_{2}+\lambda_{1} \lambda_{3}+\lambda_{2} \lambda_{3}\right)^{-1}= \\
& =(w+\bar{w}+a+b+k) \times
\end{aligned}
$$


$\times[(w+\bar{w})(b+k)+a(w+k)]^{-1}$,

а найповільніші, загрублені процеси, що лімітують остаточне спустошення станів системи, відповідають ефективному часу

$\tau_{\text {eff }}=1 / \lambda_{1}+1 / \lambda_{2}+1 / \lambda_{3}=\frac{\tilde{a}(1+k / w)+b+k}{k \tilde{a}}$,

де

$\tilde{a} \equiv \frac{a}{1+\bar{w} / w}$

є гаданою константою швидкості заповнення вихідного стану. Отже, замість використання часів $\lambda_{3}^{-1}<$ $\lambda_{2}^{-1}<\lambda_{1}^{-1}$, що за довільного їх розподілу мусять шукатися в (12) числовими методами, кінетичний опис системи (11) можна вести аналітично (13)-(16) на шкалі розподілених часів $\tau_{\text {eq }} \ll \tau_{\text {st }} \ll \tau_{\text {eff }}$. Це може надати результатам більшої фізичної прозорості, зокрема при аналізі динамічних характеристик системи.

Рівняння (11)-(13) з урахуванням (14)-(17) дозволяють отримати точні вирази для величин окремих інтегральних виходів $\theta_{i}=\int_{0}^{\infty} d t P_{i}(t)$ та сумарного інтегрального виходу $\theta_{\mathrm{eff}}=\int_{0}^{\infty} d t P(t)$ станів системи, які за визначенням є інтегралами по всьому часовому інтервалу від окремих заселенностей $P_{i}(t)$ та сумарної заселенності $P(t)=\sum_{i=1}^{3} P_{i}(t)$. Величини цих виходів, що мають зміст динамічних тривалостей спустошення відповідних станів, подано виразами

$\theta_{1}=\frac{1}{k} ; \quad \theta_{2}=\frac{K}{k} ; \quad \theta_{3}=\frac{1+\theta_{2} \bar{w}}{w} ; \quad \theta_{\mathrm{eff}}=\tau_{\mathrm{eff}}$,

де $K=(b+k) / a-$ константа рівноваги вихідного стану. Рівняння (18) показують, що динамічна тривалість $\theta_{1}$ спустошення вихідного стану визначається тільки часом $1 / k$, який задається для кінетичного каналу незворотного розпаду в системі. При цьому величина $\theta_{1}$ та тривалість $\theta_{2}$ спустошення проміжного стану задовольняють загальну рівність

$\frac{\theta_{1} K}{\theta_{2}}=1$

яка не залежить від вхідної стадії. 3 іншого боку, динамічна тривалість $\theta_{\text {eff остаточного (ефективного) }}$ спустошення станів збігається із ефективним (найповільнішим) часом $\tau_{\text {eff }}(13),(16)$ кінетичного розвитку системи. На відміну від $\theta_{1}$ та $\theta_{2}$, величина $\tau_{\text {eff }}=\theta_{\text {eff }}$ суттєво залежить від констант швидкостей вхідної стадії (14), (15). Ця залежність проявляється як безпосередньо через час спустошення вхідного стану $1 / w<\theta_{3}(18)$, так й опосередковано через константу рівноваги $\bar{w} / w$ для об'ємної стадії відносно проміжного стану. Остання впливає на швидкість а заповнення вихідного стану через зменшення її до певної гаданої величини $\tilde{a}(17)$.

Надалі треба буде, напевно, визначити, як саме величини $a, w, \bar{w}$ можуть залежати від чисел контактних положень ліганду в об'ємній та гетерогенній фазах. Оскільки такі числа прямо зв'язуються із об'ємною концентрацією ліганду та ентропійними факторами, то так можна буде знайти конкретні співвідношення між параметрами для моделі трьох станів на рис. 1 та відповідними величинами $A, W, \bar{W}$ для загальної системи (9). Для цього, однак, треба розглянути певну модель, що описує динаміку ліганду в об'ємній та гетерогенній фазах.

Нехай величина $\bar{W}=D / \Delta l^{2}$ визначає ймовірність дифузійного стрибка ліганду у розчині з коефіцієнтом дифузії $D$ на довжину $\Delta l$, що відповідає відстані між його сусідніми контактними положеннями. Ця ж ймовірність визначає стрибок ліганду із довільного стану гетерогенної фази у довільний стан гомогенної фази. Якщо початковий стан ліганду у розчині є випадковим, то можна зіставити його контактні положення із центрами на деякій регулярній або розупорядкованій гратці. Тоді за теоремою теорії графів [31] найбільш імовірною кількістю стрибків, за якою ліганд буде долати відстань між довільними центрами, $€ M^{1 / d}$, де $M-$ кількість центрів гратки у розрахунку на один ліганд, а $d$ - розмірність гратки. Якщо центри гратки еквівалентні і з'єднуються між собою так, щоб ймовірності переходів між ними були однакові, то топологія такої гратки буде ергодичною, її розмірність збігатиметься із розмірністю деякої поверхні $(d=2)$, а стани ліганду на гратці - стануть виродженими. У рівноважному випадку можна перейти від тотожних станів ліганду в об'ємі розчину до одного сумарного $\aleph_{V} N$ - кратно виродженого стану $i=3[32,33]$, а також від станів ліганду в гетерогенній фазі до $\aleph_{S}-$ кратно виродженого стану $i=2$. Це приведе до зменшення ймовірності ефективного стрибку із сумарного стану $i=3$ у сумарний стан $i=2$ по відношенню до ймовірності зворотного стрибка в $\mathfrak{R} N$ раз з відповідним фактором гетерогенності $\mathfrak{R} \equiv \aleph_{V} / \aleph_{S}$ :

$w=\frac{W}{\aleph_{S}}=\frac{\bar{W}}{\aleph_{V} N}=\frac{\bar{w} C}{\mathfrak{R}}$.

У нерівноважному випадку поряд з $\aleph_{V} N$ об'ємними станами ліганду треба розглядати також середню відстань $\bar{l}$, яку долає ліганд, мандруючи в об'ємній фа- 
зі до контакту з гетерогенною фазою. За ергодичної початкової умови ця відстань $є \bar{l}=\Delta l \sqrt{\aleph_{V} N}$. Тому для ефективного стрибка на таку відстань отримуємо ймовірність $w=D / \bar{l}^{2}=\bar{w} / \mathfrak{R} N$, що збігається 3 (20). Аналогічно, для гаданої константи $\tilde{a}$ (17) маємо

$$
\tilde{a}=\frac{A}{\aleph_{V} N+\aleph_{S}}=\frac{a C}{C+\Re},
$$

де $a=A e^{-\sigma}$, а $\sigma \equiv \ln \aleph_{S}-$ ентропійний фактор (у натуральних одиницях), що виявляе перевагу сукупного положення ліганду над локальним у гетерогенній фазі.

Загалом кінетична схема для переходів у системі трьох станів із незворотною стадією, що розглядалась в цьому розділі, із урахуванням встановлених за формулами (20), (21) закономірностей для констант швидкостей її вхідних стадій, є базовою моделлю для узагальненого тристадійного незворотного процесу. Він повністю відображає задачу, що ставилась у другому розділі для опису нестаціонарної динаміки релаксаційних переходів у відкритих квантових системах. При цьому треба вважати, що в кінетичній моделі, наведеній на рис. 1, константи швидкостей містять усереднені внутрішні та зовнішні параметри, варіація яких впливає на динамічні характеристики системи.

\section{5. Спрощена кінетика незворотних процесів}

При аналізі даних, що спостерігаються, поряд з виразами для заселенностей (11) у вигляді суми трьох експоненційних компонент, треба також мати спрощені вирази, які містять суми двох таких компонент чи навіть подаються як одна компонента. Однак для цього в (13)-(16) треба вказувати, яка із трьох кінетичних стадій - об'ємна, гетерогенна чи стадія розпаду - відіграє головну роль у встановленні в системі локальної рівноваги. Із загальних фізичних міркувань можна вважати, що гетерогенні процеси із часами релаксації $(a+b)^{-1}$ будуть протікати набагато повільніше від об'ємних процесів, що характеризуються часами $(w+\bar{w})^{-1}$ :

$a+b \ll w+\bar{w}$.

Крім того, щоб оперувати не дуже малими амплітудами заселенностей перехідних станів, можна припускати, що характерна швидкість $k$ спустошення кінцевого стану на стадії незворотного розпаду має бути набагато меншою за відповідну швидкість $w$ заповнення проміжного стану на вхідній стадії:

$k \ll w$.
Таким чином, у подальшому можна покладати, що локальна рівновага в системі досягається за рахунок надшвидких процесів якраз в об'ємній фазі.

Умови $(22),(23)$ визначають квазістаціонарне наближення $a+b+k \ll w+\bar{w}$ для проміжної й вихідної стадій відносно рівноважної вхідної стадії. Це еквівалентно до виконання в (13) і (12) напівсильних нерівностей $\tau_{\text {eq }} \ll \tau_{\text {st }}<\tau_{\text {eff }}$ і $\lambda_{3} \gg \lambda_{2}>\lambda_{1}$ відповідно. Тому точні трьохекспоненційні вирази (11) трансформуються до спрощеного вигляду із двома експонентами:

$$
\begin{aligned}
& P_{2}(t)=\left(\lambda_{2}-\lambda_{1}\right)^{-1}\left[\left(\lambda_{2}-\tilde{a}\right) e^{-\lambda_{1} t}+\left(\tilde{a}-\lambda_{1}\right) e^{-\lambda_{2} t}\right] \\
& P_{1}(t)=\tilde{a}\left(\lambda_{2}-\lambda_{1}\right)^{-1}\left[e^{-\lambda_{1} t}-e^{-\lambda_{2} t}\right]
\end{aligned}
$$

де

$\lambda_{1,2}=\frac{1}{2}\left[(\tilde{a}+b+k) \mp \sqrt{(\tilde{a}+b+k)^{2}-4 \tilde{a} k}\right]$.

При цьому наближений кінетичний опис системи буде вестись на рівноважних часах дискретизації $\Delta t>\tau_{\text {eq }}$ (14). Ці часи за своєю суттю будуть цілком аналогічними часам дискретизації для коливальної $\tau_{\text {vib }}$ та флуктуаційної $\tau_{\nu} \sim \tau_{\gamma}$ рівноваг, що вводились у другому та третьому розділах, хоча за величиною будуть значно перевищувати їх: $\Delta t>\tau_{\text {eq }} \gg \tau_{\text {vib }} \sim \tau_{\nu} \sim \tau_{\gamma}$.

Як бачимо, при виконанні $(22),(23)$ швидка кінетична компонента $P_{3}(t) \sim e^{-\lambda_{3} t}$ в $(11)$, що характеризує об'ємну стадію, із виразів (24) зникає, але при збереженні усередненої інформації про неї у гаданій швидкості $\tilde{a}(17)$. Якщо ж тепер допустити в (13) і (12) виконання більш сильних нерівностей $\tau_{\text {eq }} \ll \tau_{\text {st }} \ll \tau_{\text {eff }}$ i $\lambda_{3} \gg \lambda_{2} \gg \lambda_{1}$, відповідно, то із розгляду поряд 3 об'ємною компонентою зникатиме також гетерогенна компонента $P_{2}(t) \sim e^{-\lambda_{2} t}$. У цьому випадку опис системи загрубиться до однієї компоненти:

$P_{1}(t)=\mathrm{P}_{1}^{\mathrm{st}} e^{-t / \tau_{\text {eff }}}$,

де $\mathrm{P}_{1}^{\text {st }}=\tilde{a} /(\tilde{a}+b+k)$ - амплітуда заселенності $P_{1}(t)$ вихідного стану, яка встановлюється у стаціонарному режимі. Однак такий загрублений опис уже не буде повним. Дійсно, на відміну від сумарної заселеності $P_{1}(t)+P_{2}(t)$ в $(24)$, заселеність $P_{1}(t)$ в $(26)$ спадатиме до нуля не від одиниці при $t=0$, а від меншої за одиницю величини $\mathrm{P}_{1}^{\mathrm{st}}<1$. Згідно з (18), (21), (25) ця величина буде залежати від об'ємної концентрації $C$ ліганду за модифікованою ізотермою Ленгмюра:

$\mathrm{P}_{1}^{\mathrm{st}}=C[C(1+K)+\Re K]^{-1}$. 
Це приведе до можливості варіації $\mathrm{P}_{1}^{\text {st }}$ у широких границях від нуля при $C=0$ до $(1+K)^{-1}<1$ при $C \rightarrow \infty$. Ця ж величина буде фактично визначати відповідні часи стаціонарного заповнення і ефективного спустошення станів $(23)-(26),(15),(16)$ :

$\tau_{\text {st }}=\mathrm{P}_{1}^{\mathrm{st}}(\tilde{a})^{-1} \quad$ i $\quad \tau_{\text {eff }}=\left(\mathrm{P}_{1}^{\mathrm{st}} k\right)^{-1}$.

Отже, формула (26) при $t=0$ практично не працюватиме, а буде виконуватись лише на стаціонарних часах дискретизації $\Delta t>\tau_{\mathrm{st}} \gg \tau_{\mathrm{eq}}(14),(15)$. I тільки після того, як ці часи минуть, стане можливим одноекспоненційний опис поведінки системи (26), який буде характеризуватися ефективним часом $\tau_{\text {eff }} \gg \tau_{\text {st }}$ (16), (28).

Наголосимо, що при $\tau_{\text {st }} \ll \tau_{\text {eff }}$ або при $\tilde{a} k<\tilde{a}(b+$ $k) \ll(\tilde{a}+b+k)^{2}(16),(28)$ виконується нерівність

$\mathfrak{D}_{1}=\mathrm{P}_{1}^{\mathrm{st}}\left(1-\mathrm{P}_{1}^{\mathrm{st}}\right) \ll 1$.

Тут $\mathfrak{D}_{1}$ має зміст дисперсії для розподілу випадкової амплітуди стаціонарного бінарного процесу із ймовірністю $\mathrm{P}_{1}^{\text {st }}$, причому величина $\mathfrak{D}_{1}$ зв'язується iз невизначеністю в отриманні певних значень амплітуд. Тому нерівність (29) фактично означає, що досягнення максимальної визначеності (чи мінімальної невизначеності) для амплітуд заселенностей перехідних станів потребує, щоб процес гранично наближався до стаціонарного. Згідно з (27) це обмежує застосовність розв'язку Бріггса-Халдейна для задачі Міхаеліс-Ментен у стаціонарному режимі [34], зводячи його тільки до випадку дуже великої концентрації $C \gg K$ та/або значної спорідненості $K^{-1} \gg 1$ ліганду до рецептора. У випадках помірних $C$ та $K$, коли нерівності $(23),(29)$ не виконуються, треба користуватися більш точними рівняннями (11)-(18) або їх спрощеними аналогами (24),(25).

\section{6. Вплив параметрів системи на динаміку перехідних станів}

Знаючи аналітичні залежності заселенностей станів від швидкостей кінетичних стадій (11)-(13) та маючи залежності цих швидкостей від структурних (релаксаційних, флуктуаційних, ентропійних) факторів (10), (20), (21), можна проаналізувати вплив макроскопічних параметрів - концентрації, в'язкості і температури - на динаміку станів системи. Оскільки такий вплив розрізняється для різних фаз, розглянемо такі параметри окремо. Зазначимо, що за ергодичних умов для схеми на рис. 1 концентрація $C$ ліганду впливає лише на вхідну швидкість $w$ заповнення проміжного стану (20) й тільки через неї діє

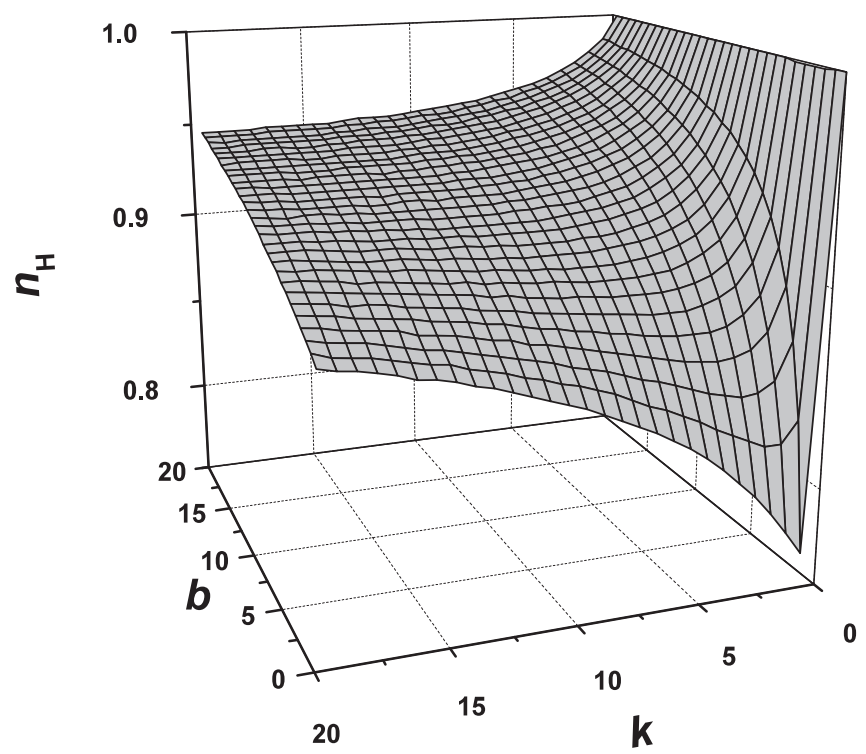

Рис. 2. Залежність коефіцієнта Хілла $n_{\mathrm{H}}$ від констант швидкостей $b$ та $k$ у схемі, наведеній на рис. 1 за умов $w / \bar{w}=\tilde{a} / a=$ $C / \mathfrak{R} \ll 1$

на інші параметри системи (14)-(28). Тому, фіксуючи обернену до $w$ швидкість $\bar{w}$ на певному значенні за умови $w / \bar{w}=C / \mathfrak{R} \ll 1$, можна вивчати в (11) концентраційну залежність як функцію відносної зміни $\overline{\mathrm{P}}_{1} /\left(1-\overline{\mathrm{P}}_{1}\right)$ амплітуди заселеності вихідного стану $\overline{\mathrm{P}}_{1}=\max \left\{\mathrm{P}_{1}(0 \leq t<\infty)\right\}$ від величини $\tilde{a}=a C / \mathfrak{R}$ (20), (21). У подвійному логарифмічному масштабі нахил цієї функції буде збігатись із коефіцієнтом Хілла $n_{\mathrm{H}}$, що описує кооперативність системи [35] за їі максимальної здатності контрольовано варіювати амплітуду своїх динамічних характеристик при зміні концентрації. При цьому, якщо $n_{\mathrm{H}}=1$, система вважається не кооперативною, $n_{\mathrm{H}}>1$ означає позитивну кооперативність, а $n_{\mathrm{H}}<1$ свідчить про "негативну" кооперативність. На рис. 2 показано конкретний приклад появи кооперативного ефекту за певної зміни кінетичних параметрів у (11). У випадку граничної стаціонарності (29) концентраційна залежність амплітуди вихідного стану $\overline{\mathrm{P}}_{1}(C)$ має збігатись із такою для стаціонарної величини $\mathrm{P}_{1}^{\text {st }}(C)$ і тому повинна описуватися некооперативною (ленгмюрівською) концентраційною залежністю (27). Як видно з рис. 2, цей випадок може реалізуватися лише в дуже вузькій області зміни параметрів, коли константа швидкості незворотного розпаду вихідного стану знехтувально мала. Практично для всіх інших значень параметрів система демонструє негативну кооперативність, причому найменше значення з величин $n_{\mathrm{H}}<1$ досягається у гранично нестаціонарному режимі, коли два $з$ трьох 
коренів характеристичного рівняння (12) стають виродженими: $\lambda_{1}=\lambda_{2} \ll \lambda_{3}$.

Як випливає з рівняння (10), швидкості релаксаційних переходів повинні залежати саме від флуктуаційної півширини рівнів $\gamma$. Однак така залежність проявляється переважно для однофононних квазіізоенергетичних переходів, коли частоти переходів у системі збігаються із частотами коливань в оточенні та є малими у порівнянні 3 тепловою частотою $\left|\Omega_{m m^{\prime}}\right|=\omega_{\lambda} \ll \omega_{T}$. До такого належать переходи, які відбуваються в гомогенній фазі, де параметр $\gamma$ відповідає коефіцієнту тертя, що пропорційний в'язкості. За використання одномодового представлення для спектральної функції $J=$ $\left(2 \pi / \hbar^{2}\right) \sum_{\lambda} \sum_{m m^{\prime}} \omega_{\lambda}^{-1}\left|\chi_{m m^{\prime}}^{\lambda}\right|^{2} \delta\left(\left|\Omega_{m m^{\prime}}\right|-\omega_{\lambda}\right) \quad 3 \quad(10)$, (21) отримуємо

$w=\frac{\bar{w}}{\Re N}=\frac{D}{\Delta l^{2} M}=2 J \frac{k_{\mathrm{B}} T}{\hbar \gamma}$.

Тут залежність від в'язкості $\gamma$ проявляється через коефіцієнт дифузії $D$, який підпорядковується співвідношенню Ейнштейна $D=2 k_{\mathrm{B}} T / \gamma$. Водночас 3 (30) маємо $J=\hbar / \Delta l^{2} M$. Тобто спектральна функція $J$ відповідає кванту $\hbar$ найменшої дії, що відноситься до дисперсії елементарних зміщень $\Delta l^{2}$, які викликаються такою дією, та кратності $M$ виродженості станів системи. Це означає, що $J$ залежить тільки від структурних факторів релаксаційної взаємодії та характеристичних коливань у системі [27], тоді як $D$ містить інформацію про макроскопічні параметри системи, такі як в'язкість і температура.

Маючи точні вирази (11)-(16), бачимо, що ефекти в'язкості (30) можуть проявлятися головним чином у сильно вироджених системах $M \gg 1$ (малі $C$ ) завдяки члену $\sim k / w$, що входить до часу $\tau_{\text {eff }}(16)$ ефективного спустошення станів тристадійної моделі (рис. 1). Але при збільшенні $\gamma$ буде відбуватися лише слабке підвищення $\tau_{\text {eff }}$ на фоні незначного падіння амплітуди $\overline{\mathrm{P}}_{1}$ вихідного стану (11) при зростанні інтегральних виходів сумарного $\theta_{\text {eff }}$ і вхідного $\theta_{3}$ станів $(18)$. Крім того, за малих $C$ динамічні характеристики системи матимуть дуже незначні амплітуди, величина яких буде однаковою із ї похибкою. Тому ефекти в'язкості, напевно, не будуть мати достовірного прояву на стадіях кінцевого спустошення станів системи.

Наприкінці зупинимось на температурних залежностях, що можуть проявлятися у перехідних процесах. Це є загальною проблемою, оскільки практично всі швидкості переходів у той чи інший спосіб та до більшої або меншої міри мають залежати від температури. У деяких випадках температурні залежно- сті цілком піддаються кількісному аналізу й відповідно систематизуються $[26,27,36-39]$. Але для більшості перехідних процесів такі залежності залишаються невизначеними. Перш за все, це стосується кінетичних та динамічних параметрів, що входять до сум експонент у виразах для заселенностей перехідних станів (11). За варіації зовнішніх умов, зокрема температури, оцінка значень цих параметрів становить математично погано поставлену обернену задачу [40-42] і може бути принципово неточною. Значно менше це торкається інтегральних виходів станів (18). Ці величини безпосередньо пов'язуються із динамічними характеристиками для окремих кінетичних стадій системи. Тому вони допускають регресивний аналіз у термінах прямої добре поставленої задачі. Наприклад, інтегральний вихід $\theta_{1}$ кінцевого стану однозначно характеризує тривалість його спустошення $1 / k$, яка іноді виявляється зовсім незалежною від температури [26, 39]. Навпаки - інтегральний вихід $\theta_{2}$ проміжного стану залежить від константи рівноваги $b / a$ гетерогенної стадії. Ця величина має значну температурну залежність, переважний внесок у котру дає швидкість $b$ ендотермічної дисоціації ліганду з рецептора. Такий процес характеризується найбільшою для системи енергією активації, яка згідно з (10) оцінюється як $E^{a}=\hbar \Omega_{21} \gg k_{\mathrm{B}} T$. Важливо, що саме ця енергія безпосередньо вимірюється в експерименті [39]. Тому, знаючи величину $E^{a}$ та покладаючи у відповідності до (9) і рис. $1 b=B=A \exp \left(-E^{a} / k_{\mathrm{B}} T\right)$, з урахуванням встановленої залежності (21) знаходимо таку верхню межу для ентропійного фактора:

$\sigma \leq \ln \frac{b}{a}+\frac{E^{a}}{k_{\mathrm{B}} T}$

$\mathrm{y}$ роботі [39] показано, що для $P 2 X_{3}$ рецепторів, які активуються лігандами аденозинтрифосфату, типовими значеннями для константи рівноваги та енергії активації є $b / a=10^{-11} ; E^{a}=1,7 \mathrm{eB} \approx 70 k_{\mathrm{B}} T$. Враховуючи, що $\ln 10 \approx 7 / 3$, з (31) маємо пряму оцінку $\sigma \leq 44$, яку можна застосовувати до ентропійних факторів для органічних молекул у нанооб'ємах.

Схожу до $\theta_{2}$ температурну поведінку продемонстровано також за допомогою константи рівноваги $K=\theta_{2} k$ (18), яка, зокрема, входить до амплітуди $\mathrm{P}_{1}^{\text {st }}(27)$. Але оскільки температурна залежність $K$ проявляється лише при незначних $C \ll K$, коли $\mathrm{P}_{1}^{\text {st }}$ малі, такий аналіз є мало інформативним. Для більш достовірної оцінки величини $K$ потрібно застосовувати варіацію як температури, так і концентрації. При цьому можна експериментально засвідчити обгрунто- 
ваність прогнозованої теоретичної рівності (19), яка є нечутливою до такої варіації.

Як висновок, процес незворотного зв'язування ліганду із рецептором у розчині залежить від концентрації ліганду, в'язкості розчину та температури. Концентраційна залежність, що виникає завдяки факту виродженості станів відкритої системи, охоплює всі кінетичні стадії процесу. Така залежність у стаціонарній границі збігається із некооперативною ізотермою Ленгмюра (27), але у нестаціонарному випадку стає загально негативно кооперативною (рис. 2). Навпаки, залежність від в'язкості відображає флуктуації об'ємної фази системи і мало торкається гетерогенної та твердої фаз. Тому для проміжної та вихідної стадій процесу така залежність звичайно не проявляється. Нарешті, температурна залежність цілком визначається числами заповнення для коливань, що відповідають характерним частотам переходів між станами системи (10). Така залежність відображає переважно активаційні процеси, що відбуваються на межі поділу фаз. За знижених температур швидкість ендоергічних гетерогенних переходів стає експоненційно малою. Це веде до можливого виродження коренів характеристичного рівняння (12), що утруднює розділення кінетичних процесів за величинами характерних часів (13)-(16). Тому при низьких температурах незворотна система, стаючи нестаціонарною, починає проявляти негативну кооперативність, що приводить до зменшення ступеня контрольованості їі амплітудних характеристик (29).

1. Y. Jia, D.S. Talaga, W.L. Lau, H.S.M. Lu, W.F. DeGrado, and R.M. Hochstrasser, Chem. Phys. 247, 69 (1999).

2. M. Dahan, A.A. Deniz, T. Ha, D.S. Chemla, P.G. Schultz, and S. Weiss, Chem. Phys. 247, 85 (1999).

3. W.E. Moerner, J. Phys. Chem. B 106, 910 (2002).

4. M. Orrit, Single Mol. 3, 255 (2002).

5. H.P. Lu, L. Xun, and X.S. Xie, Science 282, 1877 (1998).

6. P.B. English, W. Min, A.M. van Oijen, K.T. Lee, G. Luo, H. Sun, B.J. Cherail, S.C. Kou, and X.S. Xie, Nat. Chem. Biol. 2, 87, (2006).

7. J.M. Fernandez and H. Li, Science 303, 1674 (2004).

8. D.J. Muller and Y.F. Dufrene, Nat. Nanotech. 3, 261 (2008).

9. P.W. Anderson, J. Phys. Soc. Jpn. 9, 888 (1954).

10. R. Kubo, J. Phys. Soc. Jpn. 17, 1100 (1962).

11. I. Oppenheim, K.E. Shuler, and G.H. Weiss, Stochastic Processes in Chemical Physics: The Master Equation (MIT Press, Cambridge, MA, 1977).
12. Э.Г. Петров, В.И. Тесленко, ТМФ 84, 446 (1990).

13. Э.Г. Петров, В.И. Тесленко, УФЖ 35, 1106 (1990).

14. K. Lindenberg and B.J. West, The Nonequilibrium Statistical Mechanics of Open and Closed Systems (VCH, New York, 1990).

15. V.M. Kenkre and P. Reineker, Exciton Dynamics in Molecular Crystals and Aggregates (Spriger, Berlin, 1982).

16. N.G. Van Kampen, Stochastic Processes in Physics and Chemistry (North-Holland, Amsterdam, 1984).

17. U. Weiss, Quantum Dissipative Systems, Series in Modern Condensed Matter Physics, Vol. 2 (World Scientific, Singapore, 1993).

18. E.G. Petrov, V.I. Teslenko, and I.A. Goychuk, Phys. Rev. E 49, 3894 (1994).

19. E.G. Petrov, I.A. Goychuk, V.I. Teslenko, and V. May, Physics Lett. A 218, 343 (1996).

20. E.G. Petrov, Phys. Rev. E 57, 94 (1998).

21. I. Goychuk and P. Hanggi, Adv. Phys. 54, 525 (2005).

22. Y. Jung, E. Barkai, and R.J. Silbey, Adv. Chem. Phys. 123, 119 (2002).

23. Y.R. Chemla, J.R. Moffitt, and C. Bustamante, J. Phys. Chem. B 112, 6025 (2008).

24. A.I. Burshtein, Adv. Phys. Chem. 2009, 214219 (2009).

25. J. Cao and R.J. Silbey, J. Phys. Chem. A 113, 13825 (2009).

26. E.G. Petrov and V.I. Teslenko, Chem. Phys. 375, 243 (2010).

27. V.I. Teslenko, E.G. Petrov, A. Verkhratsky, and O.A. Krishtal, Phys. Rev. Lett. 104, 178105 (2010).

28. В.А. Бендерский, Е.В. Ветошкин, Е.И. Кац, ЖЭТФ 124, 259 (2003).

29. S. Nakajima, Progr. Theor. Phys. 20, 948 (1958).

30. R. Zwanzig, Physica 30, 1109 (1964).

31. S.N. Dorogovtsev, A.V. Goltsev, and J.F.F. Mendes, Rev. Mod. Phys. 80, 1275 (2008).

32. В.И. Тесленко, УФЖ 34, 1748 (1989).

33. T.G. Lombardo, F.H. Stillinger, and P.G. Debenedetti, Proc. Natl. Ac. Sci. U.S.A. 106, 15131 (2009).

34. A. Fersht, Structure and Mechanism in Protein Science: A Guide to Enzyme Catalysis and Protein Folding (W.H. Freeman and Co., New York, 1999).

35. N.M. Goodey and S.J. Benkovic, Nat. Rev. Chem. Biol. 4, 474 (2008).

36. B.M. Rodriguez, D. Sigg, and F. Bezanilla, J. Gen. Physiol. 112, 223 (1998).

37. M.E. Peterson, R.M. Daniel, M.J. Danson, and R. Eisenthal, Biochem. J. 402, 331 (2007). 
38. J.F. Gillooly, J.H. Brown, G.B. West, V.M. Savage, and E.L. Charnov, Science 293, 2248 (2001).

39. V. Khmyz, O. Maximyuk, V. Teslenko, V. Verkhratsky, and O. Krishtal, Pflugers Arch. Eur. J. Physiol. 456, 339 (2008).

40. A. A. Istratov and O. F. Vyvenko, Rev. Sci. Instruments 70, 1233 (1999).

41. J. Fisher and T.A. Henzinger, Nat. Biotech. 25, 1239 (2007).

42. A. Raue, C. Kreutz, T. Maiwald, J. Bachmann, M. Schilling, U. Klingmuller, and J. Timmer, Bioinformatics 25, 1923 (2009).

Одержано 20.01.08

\section{ДИНАМИКА ПЕРЕХОДНЫХ ПРОЦЕССОВ В НЕОБРАТИМЫХ КИНЕТИЧЕСКИХ МОДЕЛЯХ}

В.И. Тесленко, А.Л. Капитанчук

Р е з ю м е

Для описания процесса необратимого связывания молекул лиганда и рецептора в растворе построена микроскопическая модель открытой системы, которая взаимодействует с внешней средой и испытывает квазиклассические флуктуации своей энергии. Получены аналитические выражения для вероятностей переходов между нестационарными состояниями системы, которые усредняются как по равновесным колебаниям в среде, так и по стационарным состояниям в системе. Для необратимой модели с тремя кинетическими стадиями найдены явные зависимости констант скоростей переходов от концентрации лиганда, вязкости раствора и температуры.

\section{DYNAMICS OF TRANSIENT PROCESSES IN IRREVERSIBLE KINETIC MODELS}

V.I. Teslenko, O.L. Kapitanchuk

Bogolyubov Institute for Theoretical Physics, Nat. Acad. of Sci. of Ukraine (14b, Metrolohichna Str., Kyiv 03680, Ukraine; e-mail:vtes@bitp.kiev.ua)

$\mathrm{S}$ u m m a r y

A microscopic model of an open system interacting with an external medium and exhibiting quasiclassical fluctuations of its energy has been developed. The model is used to describe the irreversible process of binding between ligand and receptor molecules in a solution. Analytical expressions for the probabilities of transitions between non-stationary states of the system averaged over both equilibrium vibrations in the medium and stationary states in the system were derived. The explicit dependences of the transition rate constants on the ligand concentration, solution viscosity, and temperature were found for the irreversible model with three kinetic stages. 